\title{
A MANUAL OF THE \\ Flowering Plants of California
}

\section{WILLIS LINN JEPSON}

UNIVERSITY OF CALIFORNIA PRESS

Berkeley, Los Angeles, London 


\section{University of California Press \\ BERKELEY AND Los ANGeles \\ California}

UNIVERSITY OF CALIFORNIA PRESS, LTD.

LONDON, ENGLAND

Copyright 1925 by Willis Linn Jepson

Copyright renewed 1953 by Helen-Mar Wheeler

Standard Book Number 520-00606-2

$9 \begin{array}{llllll}9 & 11 & 12 & 13 & 14 & 15\end{array}$ 


\section{OUTLINE OF \\ GEOGRAPHIC DISTRIBUTION OF SEED PLANTS IN CALIFORNIA}

The flora of California is one of the distinctive floras in the region of Pacifie North America. While continental floras are not sharply delimited, because there are no abrupt limits to climatic areas, it is possible, nevertheless, to determine, in a workable manner, the geographic bounds of the California flora or California province.

From the standpoint of plant provinces the term California must be defined in a sense different from that of its political boundaries. The natural biological province of California is primarily determined by its mountains and the Pacific Ocean. The two great mountain ranges, the Sierra Nevada on the east and the Coast Ranges on the west, enclose the bowl of the Great Valleythe plains of the Sacramento and San Joaquin. This main area is supplemented by two mountain masses, one (coastal Southern California) lying between the deserts and the ocean, an area very closely related botanically to the California area proper, the other mountain mass (the-Klamath Mountains) lying at the northwesterly end of the bowl and equally related to the California area. There are, then, excluded the Colorado and Mohave deserts and desert slopes in the south, and also the interior plateaus, slopes and ranges belonging to the Great Basin and extending from Inyo County to Modoc County and thence to eastern Siskiyou County.

The northern boundary of the California province requires a particular description. In the western United States, there are only two rivers, aside from the Columbia River, which break through the main Sierra-Cascade axis and drain lands of the Great Basin, the Klamath River and the SacramentoPit River. There are thus three major physical breaks or barriers in the axis. As marking botanical boundaries, neither the Sacramento-Pit Gap nor the Klamath $\mathrm{Gap}$ is of as much significance in this connection as the Rogue River. Of the various physical features which distinguish the northern margins of the California province, the Rogue River is one of the greatest importance as defining by a mainly physiological barrier the botanical boundary of the California province northward. While the Klamath Gap marks the northern or southern extension of a number of species it is of secondary importance as compared with the Rogue River. There are a large number of species of Washington and Oregon which extend south to, or nearly to, the Rogue River, while a very large number of species of California extend north to, or nearly to, the Rogue River: the significance of these two categories is markedly greater than that of those widely-ranging species which cross the Rogue. A number of California species, to be sure, cross the Rogue but extend north. ward only a short distance. Similarly a number of Oregon species cross the Rogue but extend southward only a limited distance. The Rogue, in addition, therefore, as to such species, represents a mean of the physical conditions in a transition area.

The boundaries of the botanical province of California, in the largest sense, are, therefore, the Rogue River, the crests of the main Sierran axis, and the pass in the peninsular chain of mountains at or near the southern boundary of the state. The province thus consists of the bowl of the Great Valley, its great bounding chains east and west, and the contiguous coastal mountain masses, one at the south end, the other at the northerly or northwesterly end of the oblong bowl. This region is physiographically compact, and represents a very natural biological area; although it is at once obvious that there are marked intrusions from other floral provinces. A considerable element, arctic species, from the far north, enters the region along the summits of the high Sierras, as well as many boreal species from the Hudsonian and Canadian regions which are respectively subalpine and high montane in the Sierras. Important invasions from the floras of Washington and Oregon occur at middle altitudes in the mountains or in the coastal belt; while the flora at the lower altitudes, especially southward, shows in a marked degree the mingling of a large representation of species whose main center of distribution is in northern Mexico. It is, therefore, sometimes said that there is no such category 
as a Californian flora, but, instead, a flora of the southwest United States and northern Mexico and a flora of the Northwest. To this argument the following rejoinders may be made: 1 . The mass of endemic species in the California flora is large and of very marked character, as will be shown later in this outline. 2. The province is well characterized by a large number of species which have within the province their greatest development and extend little beyond it. 3 . The species of the tongues of intrusion from neighboring floras have their highest development in botanieal provinces to the north or to the south. 4. The thrusts from the north and the south lie at altitudinally different levels or occupy separate subclimatic areas, and do not intermingle or only to a limited degree.

\section{The Life-Zones}

As a result of the varying combinations of climatic factors in the area, intensified by distance from the ocean and by altitudes, the vegetation of California is markedly stratified into horizontal bands called life-zones. Six lifezones are here recognized, the terminology in their designation being that of C. H. Merriam (Life Zones and Crop Zones in the United States, 1-79-1898), namely, 1. Lower Sonoran. 2. Upper Sonoran. 3. Transition. 4. Canadian. 5. Hudsonian. 6. Boreal. 'The isothermal lines of a temperature chart of California correspond in a general way, though not exactly, with these life-zones, while a contour rain-chart shows similar correspondence. Annual rainfall, which is slight in the deserts of the Lower Sonoran, inereases one-half inch for every one hundred feet in proceeding up the west slope of the Sierra Nevada. Insolation increases to the southward and increases markedly with altitude. Humidity is greatest along the coast and diminishes most sensibly toward the interior and in the south.

The response of species to the climatic factors varies greatly, and consequently they differ in their capacity for altitudinal distribution as well as in horizontal distribution. Certain general categories may be noted: 1. A few species occur in three or four zones, such as (a) aquaties or cosmopolites (Potamogeton pectinatus, Myriophyllum spicatum) or (b) species of wide range (Populus trichocarpa, Barbarea vulgaris, Radicula curvisiliqua, Trifolium involucratum, Hypericum anagalloides and Achillea millefolium var. lanulosa). 2. A large number of species occur in two zones (examples are Juncus bufonius, Brodiaea ixioides, Castanopsis sempervirens and Eremocarpus setigerus). 3. A large proportion of-in some cases half-the species of a zone occur only in that zone or are not well developed beyond its borders. Of these certain ones are selected as "Indicators" of the zone, or Index Species. The characteristics which determine an Index Species are: (a) restriction to the life-zone or, if it be abundant, weak transgression beyond its limits; (b) wide range in the zone; (c) abundance of individuals. It is now necessary to describe the climatic and vegetational features of the life-zones within the state of California and cite some important index-species, so far as may be done within the brief limits of this outline.

The Lower Sonoran. Zone comprises three distinctive areas: (a) Colorado Desert or Colorado Sonoran, (b) the Mohave Desert or Mohave Sonoran, (c) the Great Valley or Valley Sonoran. The two deserts are characterized by a typical desert climate. They have a low humidity and a low rainfall, the annual preeipitation varying from about 0 to 5 inches. They have high summer temperatures, averaging from $90^{\circ}$ to $130^{\circ}$; they have low winter temperatures, varying from about $15^{\circ}$ to $50^{\circ}$; and finally, as to temperature, they have a great annual temperature range and a great diurnal range. Drying winds of gale force are prevalent. The vegetation has the characteristic aspect or facies of plants of desert regions, that is, there is everywhere exhibited a marked development of structures to inhibit transpiration, or of physiological devices for the conservation of water. These various forms may be described, in general, under five headings: (a) Plants with condensed bodies such as the species of Cereus, Mammillaria, Echinocactus and Agave. (b) Plants with reduced or obsolete leaf surface, such as Cercidium torreyanum, Ephedra californica and Parosela spinosa. (c) Plants with fleshy leaves, such as Lycium andersonii. (d) Plants with resinous, woolly, or scurfy covering to 
the whole body, such as Atriplex hymenelytra, Grayia spinosa and Tidestromia oblongifolia. (e) Ephemeral annuals whose life history from germination to seeding is accommodated to the short period (often only a few weeks) of late winter or vernal rains and of moderate temperatures. These annuals are represented by numerous species and often by vast numbers of individuals. Certain shrubs or small trees show a similar adaptation in that their leaves appear only during the rains (Fouquieria splendens).

The Colorado Desert lies at a low altitude, mainly between 0 and 500 feet. Characteristic speeies of chenopods are Atriplex hymenelytra, lentiformis, polycarpa and canescens. Achyronychia cooperi is prostrate on the desert sands. Parosela emoryi and schottii are low bushes. Other common species are Astragalus sabulonum, Euphorbia eriantha, Thamnosma montana, Petalonyx thurberi, Langloisia setosissima, Chilopsis linearis, Orobanche cooperi, Filago depressa, Encelia farinosa, Palafoxia linearis and Baileya pauciradiata. Only a few species of trees occur, such as Olneya tesota, Prosopis juliffora var. glandulosa and Prosopis pubescens, all the arborescent species being limited to stream beds and the borders of springs or low-lying valleys. This desert passes gradually into the Mohave Desert; the most practicable line of separation extends from Morongo Pass easterly to Riverside Mt. on the Colorado River. The low-lying Palo Verde Valley thus falls within the Colorado Desert.

The Mohave Desert lies at a higher level than the Colorado Desert, the altitudes ranging. from about 2000 to $5000 \mathrm{ft}$., and the rainfall is usually somewhat greater. In other respects it has a desert climate similar to that of the Colorado Desert, and its vegetation presents a similar desert facies. Hundreds of square miles exhibit the dark green of Larrea tridentata var. glutinosa, a shrub commonly 3 to 6 feet high with very small resin-covered evergreen leaves, the individuals widely but rather regularly spaced in response to the meagreness of soil-water. Low shrubs or bushes of gray hue are abundant, and include such widely distributed species of the desert valleys as Atriplex confertiflora, parryi, hymenelytra, lentiformis, torreyi, polycarpa and canescens, Franseria dumosa and Encelia farinosa. Chrysothamnus nauseosus and Acamptopappus sphaerocephalus are abundant and widely distributed on the mesas, while Lepidium fremontii is a frequent low bush. Salazaria mexicana, Lycium andersonii and cooperi are roughish or spiny shrubs. Suaeda suffrutescens is characteristic of alkaline valleys, while Thamnosma montana is a snall switch plant of the arid slopes. Characteristic desert herbs are Hesperocallis undulata, Calochortus kennedyi, Chorizanthe rigida, Chorizanthe thur. beri, Eriogonum trichopodum, inflatum, baileyi and mohavense, Achyronychia cooperi, Dithyrea californica, Lesquerella palmeri, Lepidium flavum, Astragalus layneae, tricarinatus and dispermus, Petalonyx thurberi, Phacelia minor, Orobanche cooperi, Monoptilon bellidiforme, Aster carnosus, Hymenoclea salsola and Palafoxia linearis. Extensive groves of Yucca brevifolia, the individuals 16 to $30 \mathrm{ft}$. high, lend an added touch of strangeness to the xerophytic populations. Save for this one species, true trees are mainly absent except that along stream courses, about springs or in low valleys where roots may go down 20 to 70 feet to a low-lying water stratum, a few species occur, such as Prosopis juliflora var. glandulosa and Prosopis pubescens.

The Valley Sonoran comprises the plain of the Great Valley of California except the lower or central delta portion. It is a grass land formation, varying in altitude from 10 to 500 feet, with less extremes of temperature than the desert areas and a greater rainfall. In its primitive condition it is characterized by vast numbers of annuals which germinate with the winter rains and flower during the vernal period, such as Trifolium tridentatum, Gilia tricolor, Phacelia tanacetifolia, Allocarya stipitata, Orthocarpus erianthus, purpurascens and densiflorus, Mimetanthe pilosa, Layia platyglossa and Achyrachaena mollis; while very characteristic perennial herbs are Eschscholtzia californica and Grindelia camporum. Large areas of alkaline flats are encountered, especially on the west side of the valley. These have a characteristic vegetation such as Distichlis spicata, Anemopsis californica, Nitrophila occidentalis, Allenrolfea occidentalis, Atriplex cordulata, bracteosa and expansa, Spergularia macrotheca, Lepidium latipes, Astragalus tener, Trifo- 
lium fucatum, Sida hederacea, Frankenia grandifolia and Cressa cretica. On the valley floors or undulating plains the traveler finds small depressions a few yards square and a few inches deep which fill with water in the rainy season. When a little deeper, well-defined and numerous, they take the name of "hog wallows." With the coming on of the dry season the water evaporates and the beds of these pools in late spring or early summer give rise to a distinctive flora composed of such species as Lepidium latipes, Boisduvalia cleistogama and B. glabella var. campestris, Lythrum hyssopifolia, Navarretia leucocephala, Downingia elegans and pulchella, Mimulus tricolor, Psilocarphus brevissimus and Evax caulescens. The narrow curtain of trees along the streams is composed of Platanus racemosa, Populus fremonti, Salix nigra var. vallicola, laevigata and lasiandra--though the willows are not confined to the valley floors.

The Upper Sonoran Zone may often, in certain districts, be divided into two subareas, the lower foothill belt and the chaparral belt. The lower foothill belt is a grass-land formation, sometimes with a scattered growth of Quercus douglasii and Q. engelmannii. Its characteristic herbs are Odontostomum hartwegii, Chlorogalum angustifolium, Allium serratum, Collomia heterophylla, Trichostema lanceolatum and Plantago erecta. Next above the lower foothill belt is the chaparral belt, or hard chaparral, a very remarkable formation, so ealled by the writer to distinguish it from the soft ehaparral. It has an average altitude of 1000 to 4000 feet and is characterized by the presence of extensive brush lands consisting of shrubs, some of which have been reduced in size from tree species (Jepson, Silva of California, 39). Most of the species represent extreme arid-land types and possess various markedly xerophytic structures, such as small or reduced leaves, entire leaves, thickened epidermis, hard and very dense wood, vertically placed leaves, small flowers, and seeds adapted to xerophytic conditions. The most widely spread and characteristic species are Ceanothus cuneatus, divaricatus and sorediatus, Arctostaphylos glauca, glandulosa, viscida and canescens, and Cercocarpus betuloides. One of the most extreme of chaparral types in xerophytic character is Pickeringia montana. Other species associated with the chaparral species but exhibiting iess extremes of xerophytic structure, are Dendromecon rigida, Photinia arbutifolia, Rhamnus californica, Rhus diversiloba, Fremontia californica and Eriodictyon californicum. Many of the species of true chaparral grow to large size, simulate trees in shape and hence form what is called a pigmy forest. For the most part they inhabit rocky or gravelly slopes or ridges and grow on well-drained slopes. True or hard chaparral is always a mixed formation. Chamisal, characteristic of the same sub-life zone, is commonly a pure formation of Adenostoma fasciculatum.

Chaparral is, for the most part, a fretype formation and shows evidences of long-continuer fire-ravage. In all likelihood the factor of fire has contributed to the xeropiny tic eharacter of the chaparral, because fire has, without doubt, run through the chaparral belt for many thousands of years, very likely one hundred thousand years at least. Of all the genera in the chaparral the genus Arctostaphylos has the largest number of species represented in the formation and shows the most marked responses and most evident adaptations to age-old fire conditions. The responses are of two main kinds and I have named them as follows: 1. Empyroism (Empyrophytes). Under which the individual continues to live. Some species, such as Arctostaphylos glandu. losa, develop the root-erown horizontally in the form of woody platforms at and just below the surface of the ground after fire, and from these woody platforms crown-sprouts arise for the replacement of the shrub crown. As fires run year after year, or decade after decade, the woody platform continues to increase in diameter horizontally, and often become 3 to 5 feet broad. Other species, such as Adenostoma fasciculatum, form bulbous or earrot-like root-erowns which continue to enlarge under successive fires. 2 . Pyrodaptism (Daptophytes). Under which the individual dies. Certain species, such as Arctostaphylos sensitiva, are shallow-rooting and are killed outright by chaparral fires. They have not the capacity to develop root-crowns horizontally or bulbous-wise. They must depend for regeneration of the species wholly upon seeds. Seeds are produced in great abundance, germi- 
nate freely after fire and promptly establish seedlings on a burn. Such seedlings have the power to come into the reproductive stage in a short periodsometimes in five or six years. This is a elear adaptation of the species to reproduce in a span of years fewer than the years of fire interval. This species and Arctostaphylos manzanita, stanfordiana, viscida and mariposa are true fire-type shrubs.

A list of some characteristic herbaceous index species of the Upper Sonoran Zone would comprise Carex tumulicola, bolanderi and barbarae, Juncus balticus and effusus, Chlorogalum pomeridianum, Allium hyalinum, Brodiaea laxa, Chenopodium californicum, Clematis ligusticifolia and lasiantha, Sedum spathulifolium, Trifolium variegatum, Hypericum concinnum, Helianthemum scoparium, Viola douglasii, Datisca glomerata, Sanicula bipinnatifida, Emmenanthe penduliflora, Salvia columbariae, Lotus scoparius, Micropus californicus, Psilocarphus tenellus, Hemizonia virgata, Layia glandulosa, Baeria chrysostoma, Monolopia major, Helenium puberulum and the shrubs Artemisia californica and Baccharis pilularis.

Coastal Southern California lies, below about 4000 or 5000 feet, mostly in the Upper Sonoran Life-Zone. It has many Upper Sonoran species peculiar to the area or extending into Lower California. Some of the more important are: Calochortus concolor and plummerae, Quercus engelmannii, Oxytheca trilobata, Clematis pauciflora, Romneya coulteri, Streptanthus campestris, Rhus laurina and integrifolia, Ceanothus macrocarpus and spinosus, and Mimulus brevipes.

The Transition Life-Zone is well defined, especially on its lower borders. The Sierra Transition lies between average altitudes of 2000 and 5000 feet, has a mean temperature of $55^{\circ}$ to $60^{\circ}$ and an average rainfall of 25 to 35 inches. It includes the main forest belt, and is repeated in the mountains of Southern California and in the Coast Ranges, where these latter rise to suffeiently high altitudes. This life-zone is distinetive and on the whole rather definitely circumscribed. It contains, for California, a greater number of species of trees and shrubs than any other life-zone and has, in addition, a very large population of herbs.

Widely developed in some parts of the state and very narrow in others, the Arid Transition of the Great Basin underlies the lower margin of the main Humid and Sierra Transition. It is, in California, a drier and more exposed subarea, often with a preponderance of brush slopes and scattered trees. Its most characteristic species are Pinus ponderosa, Artemisia tridentata, Aretostaphylos patula, Garrya fremontii and Prunus subcordata.

The Sierra Transition has a high development and forms a broad band. It earries the less open part of the forest belt. The dominant forest species are Pinus ponderosa and lambertiana, Libocedrus decurrens and Abies concolor. Sequoia gigantea is a marked feature of this zone in the southern part of the Sierra Nevada. The dry or more open forest or forestless slopes present many shrubs of wide range such as Corylus rostrata var. californica, Ribes roezlii, Rubus parviflorus, Amelanchier alnifolia, Rhamnus rubra, Ceanothus integerrimus, velutinus and prostratus, Cornus nuttallii, Rhododendron oceidentale and Arctostaphylos patula. On the dry flats or open forest slopes typical herbs are Sporobolus confusus, Stipa elmeri, Allium campanulatum, Fritillaria parviflora, Habenaria unalaschensis, Corallorrhiza maculata, Asarum hartwegii, Silene lemmonii, Lathyrus graminifolius, Gayophytum diffusum, Pterospora andromedea, Pirola picta, A pocynum androsaemifolium var. pumilum, Gilia aggregata, Draperia systyla and Aster integrifolius. In the wet meadows or in swamps grow such species as Agrostis oregonensis, Veratrum californicum, Polygonum bistortoides, Ranunculus orthorhynchus, Heracleum lanatum, and Vaccinium occidentale.

The Redwood Transition, which comprises the coastal Redwood belt, extends from sea-level to 2000 or sometimes to 3000 feet altitude. It has, therefore, a very much lower altitude than the Sierra Transition. From the standpoint of precipitation, it is at a somewhat higher physiological level, because it has a greater rainfall, varying from 25 to 122 inches. From the standpoint of temperature it enjoys a lower annual range and lower diurnal range. Being wholly within the coastal fog belt and lying next the ocean, it has much 
greater humidity. Proceeding from the Great Valley to the coastal edge of the Redwood belt, one passes through formations similar, in an ecological view, to those met with in ascending the Sierras from the Great Valley, since there are met successively the dry barren plains, the barren foothills, the chaparral and finally a narrow band of Pinus ponderosa and Quercus kelloggii, which is Arid Transition. In its greatest development the Redwood forms pure stands. In other parts of the belt it is dominant but with it is associated Lithocarpus densiflora, Pseudotsuga taxifolia, Tsuga heterophylla, Picea sitehensis and Abies grandis. On the inner side of the Redwood belt is a marked band of Arbutus menziesii, Pseudotsuga taxifolia and Quercus garryana. The forest floor of the Redwood belt is characterized by certain herbs which, often shade-loving, occur in great abundance and are, in California, restricted to the belt, such as Torresia macrophylla, Scoliopus bigelovii, Clintonia andrewsiana, Maianthemum bifolium var. kamtschaticum, Trillium ovatum, Asarum caudatum, Vancouveria parviflora, Achlys triphylla, Saxifraga mertensiana, Oxalis oregana, Viola sarmentosa and ocellata, and Mimulus dentatus. Certain shrubs form a very low understory and often occur in heavy stands, as Ceanothus thrysiflorus, Vaccinium ovatum and Gaultheria shallon. What I have ealled soft chaparral refers to a shrub formation of the Transition Zone. It is composed of such species as Physocarpus capitatus, Holodiscus discolor, Rubus parviflorus, Vaccinium ovatum and Symphoricarpos albus. Soft chaparral occurs in the Coast Range Transition, the Redwood Transition, the Sierra Transition and frequently as islands in the Upper Sonoran.

The Canadian Life-Zone is not well defined in the Sierra Nevada and has, as a separate zone, only a shadowy or wavering existence. Its natural place is on the average between 5000 and 7000 feet, where there is a mean annual temperature of $50^{\circ}$ to $55^{\circ}$, and an average rainfall of 40 to 50 inches. The most useful index species in this life-zone are Abies magnifica, Pinus ponderosa var. jeffreyi, Pinus monticola and Pinus contorta var. murrayana. The first three species are, however, often found in the upper part of the Transition Zone, associated with typical Transition species, while the fourth is frequently a characteristic species of the next life-zone above, the Hudsonian. The following herbs and shrubs may be consirlered as belonging to this zone: Prunus emarginata, Arctostaphylos nevadensis, Nama lobbii, Hes. perochiron californicus, Mimulus lewisii and Pedicularis semibarbata.

The Hudsonian Life-Zone is the timber-line zone, and is fairly well defined as to its upper borders. It has an average altitude of 7000 to 9000 feet, a mean annual temperature of $45^{\circ}$ to $50^{\circ}$, and an average rainfall of 50 to 55 inches. The most important index species are Pinus albicaulis, Juniperus occidentalis, Juncus drummondii and parryi, Calochortus leichtinii, Salix lemmonii and geyeriana var. argentea, Polygonum shastense, davisiae and imbricatum, Eriogonum pryrolaefolium, Ribes cereum, viscosissimum and montigenum, Epilobium latifolium and obcordatum, Kalmia polifolia var. microphylla, Cassiope mertensiana, Polemonium confertum var. eximium, Castilleia culbertsonii, Orthocarpus pilosus, Pedicularis attollens and groenlandica.

The Boreal Life-Zone is true alpine. Its altitudinal range varies from 9000 to 14,500 feet, with a mean annual temperature of $40^{\circ}$ to $45^{\circ}$ and an average rainfall of 60 to 70 inches. The most important index species are Trisetum spicatum, Carex breweri and nigricans, Oxyria digyna (which extends north to the aretic circle), Silene watsonii, Ranunculus eschscholtzii (which extends north to the arctic circle), Aquilegia pubescens, Dicentra uniflora, Parrya eurycarpa, Saxifraga tolmiei and bryophora, Potentilla procumbens, fruticosa, gordonii and muirii, Epilobium anagallidifolium, Primula suffrutescens, Erigeron compositus and radicatus, Hulsea algida and Senecio muirii. Draba lemmonii, breweri and glacialis, and Eriogonum ovalifolium are typical cushion plants. The Boreal Zone presents marked plant formations on the Salmon Mountains, Mt. Shasta, Lassen Peak and the high Sierra Nevada. It recurs evidently, though represented by few species, on Mt. San Gorgonio in the San Bernardino Mountains and feebly on MIt. San Jicinto in the San Jacinto Mountains. 


\section{Irregularities in the Life-Zones}

The temperatures given above are of the Fahrenheit scale. While they are mean annual temperatures, and do not, therefore, represent the critical temperatures for plant life or plant growth, they do give an idea of the climate of the various life zones from the standpoint of temperature. However, these life-zones must not be thought of as marked by rigid horizontal lines or even by regular contour lines. The local boundaries of the zones are irregular or jagged for the following reasons:

1. Insolation increases markedly on proceeding southward, and normal tem. peratures increase correspondingly, so that, for example, the timber line on Mt. Shasta is at about 7500 feet, while on Mt. Whitney, 400 miles southeasterly, it is at 11,000 feet. In addition, normal temperatures fall with increase in altitude about $1^{\circ}$ for each rise of 330 feet (S. S. Visher, Climatic Laws, 20). That is, all the zones gradually increase in altitude southward.

2. Exposure is related to local changes in the zones. The southerly or westerly slopes of a mountain receive a greater amount of direct heat from the sun, and a forest belt or a plant formation will run much higher on such a slope. The easterly or north slopes are much cooler, since partially protected from the direct rays of the sun, and a forest or a characteristic vegetational belt will run much lower on such slopes than the average boundary of the life-zone in that region.

3. Steepness of slope affects the regularity of the zone since it causes marked local changes in drainage, temperature and insolation.

4. Accumulating blocks of hot air at lower levels may cause local variations in the boundaries of the life-zone above, sinee hot air rises along definite slopes or air-lanes, avoiding others on account of topography.

5. The flow of cold water and cold air down a cañon will cause plants of a zone to extend to lower levels in that locality.

6. Physiological Islands. By reason of local topography and moisture and temperature conditions, a small area may be isolated from its proper lifezone and yet carry characteristic index species of that zone. Such areas are called "islands." They are surrounded by physiological barriers which sometimes delimit them sharply, almost as sharply as an oceanic island surrounded by the physical barrier of salt water. A well-marked Canadian LifeZone island, carrying Pinus contorta var. murrayana, occurs in the lower part of Yosemite Valley (Transition Zone) under the shadows of the great cliffs about Bridal Veil Fall and the rock of El Capitan. A large island of the Lower Sonoran occurs in coastal Southern California between the Santa Ana and San Jacinto mountains, while a long but narrow island of the same zone occurs in the upper part of the Salinas Valley and Carissa Plain. These two islands lie in the Upper Sonoran.

7. The role of fire now and for many centuries past is and has been a major one in the Californian forests. Forests of the Transition Zone, when destroyed by fire, are often completely replaced by brush lands. In areas of deficient rainfall or slopes where high erosion results in thorough denudation of surface mulch, the brush areas may become permanent on the lower boundary of the Transition Life-Zone; such an area often goes over, in its vegetation, to the Upper Sonoran Life-Zone, and displays typical chaparral.

Expression of the distribution of life by means of the life-zone concept, while imperfect, furnishes a practical working plan from which may be derived substantial and useful results, especially in the light thrown on the problem of species. Botanists in flat countries, as in the eastern United States, often evince strong distrust of the life-zone concept but it is to be said that these vegetational bands are marked actualities in a region where mountains rise from or near sea-level to heights of from 10,000 to 14,500 feet within a distance of ten to thirty miles, and where localized climatic areas bring hygrophytic forests within a short distance of arid deserts. The life-zone nomenclature has a practical value as giving expression to certain observa. tions and will remain useful until this concept is replaced by a superior bypothesis. The concept of centers of distribution as worked out by $C$. C. Adams (Biol. Bull. 3: 115-131-1902; 9: 53-71-1909) is one which may give a clearer 
and more truthful picture of geographic distribution. Analysis of our flora along such lines must, in the main, look to the future, although the chaparral formation has been intensively studied by W. S. Cooper and the results published in an admirable paper (The Broad-Sclerophyll Vegetation of California, 1-124, pl. 1-20). In this brief sketch of the life-zones only the broaldest outlines are indicated, the statements are condensed, and the short lists of species are purely illustrative or suggestive.

\section{Plant Distribution and Geologic History}

Even an outline of geographic distribution of plants in California and the main factors causing distribution as we find it, would be incomplete without a short note on the relation of local floras to geologic history, since the earth movements on the California coast in recent geologic periods, especially since the Pleiocene, have been numerous, with subsidence and uplift of great extent. It is to such physiographic changes that we must appeal for explanation of certain restricted floras or "islands." Along the coast of California grow a number of local species, either highly localized or limited in range and thus forming "islands" or floristic remnants. Cupressus macrocarpa and goveniana form a snall "island" at Monterey, Pinus radiata occurs in small "islands" at Ano Nuevo Point, Monterey, San Simeon, and on two of the Santa Barbara islands, while Pinus torreyana occurs in two small "islands," one at San Diego, the other on Santa Rosa Island. Lyonothamnus floribundus is confined to four of the Santa Barbara Islands. Pinus muricata is rather localized on the north coast.

During the Pliocene there was elevation of the whole west coast and the Sierra Nevada became elevated again. At the close of the Pliocene and in early Quaternary the elevation of the west coast continued, causing great cañons to be formed in the Sierras and Coast Ranges. In the early Quaternary the Coast Ranges stood 2000 to 3000 feet higher than now. Increasingly lower temperatures accompanied this period of elevation and culminated in the Glacial Fpoch; the Sierra Nevada was covered with glaciers and a much higher rainfall prevailed than at the present time, especially in the coastal region (J. P. Smith, Sci. 30:346-351-1909). It seems certain that during the Glacial Epoch, an extensive hygrophytic forest stretehed southward along the south coast and that, due to elevation, the continental area included the Santa Barbara Islands, ar. 7 that, following uplift and subsidence, more arid conditions ensued and the insular species were left as littoral relicts.

During the Glacial Epoch the main mass of the California flora of lower altitudes must have migrated southward. After the Glacial Epoch another era of subsidence began, carrying the shore line 300 to 700 feet lower than now. After this a renewed elevation was followed by a subsidence which flooded coastal valleys, resulting in the present shore-line harbors. With the final migration of the flora northward, after the Pleistocene, there was introduced or developed in the Great Valley and in the foothills a flora, profuse and diversified, that has its relationships or origins mainly with the regions southward, chiefly in northern Mexico.

The Coast Ranges are the most recent of the great structural features of California. At times, during the Eocene and Pleiocene, and again in the Pleistocene, the Great Valley was an inland sea (W. C. Anderson, Proc. Cal. Acad. ser. 4, 3:6, 7, 32-1908) and into it the sea-waters from the ocean ran through one or more of the tidal gaps of the Carquinez, Pacheco Pass, Panoche Pass and Waltham Pass. The relicts found on the summits of Mt. St. Helena, Mt. Diablo, Mt. Hamilton and Loma Prieta are doubtless connected with this history: such endemic relicts as Allium breweri, Streptanthus hispidus, Sanicula saxatilis, Phacelia phacelioides (and perhaps F. breweri), and Cam. panula exigua, all of which are survivals on the mountain peaks.

The Yollo Bolly, Scott, Salmon, Marble, and Siskiyou mountains form a group of chains known geologically as the Klamath Mountains (J. S. Diller, Bull. U. S. Geol. Sur. no. 196). Their rocks are older and harder than those of the Coast Ranges and similar to those of the Sierra Nevada. During the Miocene the Coast Ranges were submerged and during the Pleistocene there 
was a downward movement of 1500 feet of the whole coast of northern California and southern Oregon. This succession of movements, subsidence and uplift, helps to explain localized distribution. In the region of the "Klamath Mountains" there occur a number of species restricted to that area and not recurring in neighboring areas, such as Picea breweriana, Quercus sadleriana, and garryana var. breweri, Lewisia cotyledon and oppositifolia, Draba howellii, Saxifraga fragarioides, Potentilla daucifolia and howellii, Rhamnus californica var. occidentalis, Viola cuneata, and Pedicularis howellii. There also occur in the Klamaths some equally marked or singular species which are not found elsewhere except in the southem Sierra Nevada. These are Pinus balfouriana, Erythronium eitrinum, Lewisia leana, Dicentra pauciflora, Hazardia whitneyi, and Raillardella scaposa var. pringlei.

At the north end of the oblong bowl of the Great Valley the landmark of Mt. Shasta rises to 14,350 feet. It is a volcanic cone of quite symmetrical outline, save for the subsidiary cone, Shastina. The mountain is of more recent origin than the Sierran axis or Klamath group, and in consequence does not belong historically either with the Sierra Nevada or Klamath Mountains, but is a part of the volcanic chain of Cascade peaks, namely, Mt. Pitt, Mt. Mazama, Mt. Hood, and Mt. Adams. Its flora is less rich than that of the high Sierras, and although its summit for about 5000 feet lies within the Boreal Zone, it carries a less number of the boreal species that distinguish the high peaks of the Sierra Nevada, Mt. Dana, Mt. Lyell, Mt. Goddard, Mt. Whitney, and many others. Ranunculus eschscholtzii is a true boreal found on high Sierran peaks and is one of few species which goes north to the aretic circle, but it is not found on Mt. Shasta. Other boreal or high montane Sierran species not found on Mt. Shasta are Lewisia nevadensis, Draba lemmonii, breweri and glacialis, Mitella breweri, Phyllodoce breweri, Primula suffirutescens, Gentiana holopetala, Chrysopsis breweri, Hulsea algida, and Raillardella scaposa. Leucothoe davisiae of the northern Sierra Nevada does not oceur on Mt. Shasta but recurs in the Klamath Mountains area westerly. Gaultheria humifusa is likewise common to the two regions just mentioned, but is not known on Mt. Shasta. This list can be extended by a perusal of the body of this text (cf. also C. H. Merriam, Biological Survey of Mt. Shasta, $75)$.

Lassen Peak is similar to Mt. Shasta in that it belongs to the Cascade group of peaks. While it is, like Mt. Shasta, weak in boreal elements, it is, however, only 10,437 feet in altitude and is probably relatively stronger than Mt. Shasta in true alpines. For example, Arenaria nuttallii, Draba aureola, and Gentiana newberryi are found on Lassen Peak but not on Mt. Shasta. Other species which occur on Lassen Peak but have not been found on Mt. Shasta are Trifolium lemmonii, Collomia larsenii, Mimulus leptaleus, Raillardella argentea, and Senecio pauciflorus.

\section{The Endemic Populations}

This Manual deseribes a total of 4019 species, 3727 of these being native plants, aside from 292 species of alien immigrants. Of these native species, 1416 species are endemic, that is, they are found only in the region covered by this Manual, the state of California. In other terms, the endemic species are about 40 per cent of the whole native population. A certain portion of the endemics have a rather wide range in the state and may be called broad endemics; other have a narrow range or are confined to a single station or a few associated stations and are called narrow endemics. Narrow enclemics may be of two kinds and owe their restricted status to essentially different causes. First, we have narrow endemics which are relicts or reliquial species persisting in a locally favorable station, being remnants of a once wide distribution. Second, narrow endemics may be species which have recently originated at that station and have not yet been afforded opportunity for wide distribution. Very remarkable endemics are Lyonothamnus floribundus, Carpenteria californica and Arctostaphylos myrtifolia. On morphologic, systematic, and geologic grounds these species may be regarled as reliquial species, while on similar grounds Downingia concolor and D. ornatissima may be considered as recent species. In the case of broad endemics definite 
endemism areas in certain cases emerge as our knowledge of species and their distribution becomes lnown in greater detail. They are closely involved with the life-zone areas and are of ten best considered as subareas of the life-zones with marked longitudinal limits. Some of the most outstanding or most significant of these endemism areas with their characteristic endemics I have named as follows:

1. The Low Foothill Area. An area of the Upper Sonoran Zone surrounding the Great Valley and extending out into its rolling, gravelly or more clevated plains: Pinus sabiniana, Odontostomum hartwegii, Chlorogalum angustifolium, Brodiaea multiflora and volubilis, Calochortus luteus, Fritillaria pluriflora, Chorizanthe membranacea, Silene californica, Isopyrum occidentale, Calycanthus occidentalis, Lithophragma affinis, Potentilla elata, Lathyrus sulphureus and californicus, Linum californicum, Aesculus californica, Oenothera graciliflora, Eulophus californicus, Linanthus filipes, Collinsia sparsiflora, Pogogyne douglasii, Galium bolanderi, Microseris acuminata, Lessingia virgata, Calycadenia truncata and ciliosa, and Lagophylla dichotoma. The altitudinal range of the Low Foothill Area is about 100 to 1500 (or 3000 ) feet.

2. The Tehaman Area. An area of the Transition Zone, forming a curved band, somewhat like an inverted $U$, extending from Lake Co. to Shasta Co. around the head of the Sacramento Valley, thence southerly from Shasta Co. to Mariposa Co., at about 3000 to $7000 \mathrm{ft}$. Sometimes an endemic of this area extends into southern Oregon. The following are to be noted: Cupressus macnabiana, Schoenolirion album, Calochortus coeruleus and nudus, Polygonum davisiae, Eriogonum ursinum, Berberis pumila, Peltiphyllum peltatum, Boykinia major, Brickellia greenei, Madia bolanderi, Senecio mendocinensis, Crepis acuminata var. pleurocarpa, and Erigeron miser. The climatic significance of this area is emphasized by species of Washington and Oregon which enter it from the north and whose range in California is nearly or quite coextensive with the area: for example Melica subulata, Carex densa and laeviculmis, Lithospermum ruderale and Chamaesarcha nana.

3. The Tehachapan Area. An area somewhat like an ox-bow set on end, extending in the Transition Zone from the San Bernardino Mountains through the San Gabriel Mountains to Mt. Pinos and Frazier Mountain, thence through the Tehachapi Mountains to the southern Sierra Nevada in Kern and Tulare counties: Oxytheca parishii, Potentilla wheeleri, Astragalus pachypus (at low altitudes), Collinsia childii, Pentstemon rothrockii, Aster adscendens var. delectabilis, Wyethia ovata, Chaenactis santolinoides and Senecio ionophyllus. The genus Oreonana is limited to this area.

4. The Mohavan AREa. An area of the lower Sonoran Life-Zone, about coextensive with the Mohave Desert: Calochortus palmeri, Chorizanthe spinosa (a narrow endemic), Oxytheca watsonii and luteola, Canbya candida, and Nicolletia occidentalis.

5. The Death Valley Area. An area of the lower Sonoran Life-Zone inclusive of the bounding foothills of Death Valley: Phyllogonum luteolum, Boerliaavia annulata, Oxystylis lutea, Astragalus atratus var. panamintensis, Brickellia knappiana, Salvia funerea, Viguiera reticulata and Enceliopsis argophylla var. grandiflora.

6. The Kĺamath Area. Deseribed above in the section on Geologic History.

7. Thr Napa-Lake Area. An area including the lower mountains ( 800 to $3000 \mathrm{ft}$.) and valleys in northern Napa Co. and Lake Co.: Brodiaea rosea, Chorizanthe clevelandii, Delphinium uliginosum, Astragalus clevelandii, Antirrhinum virga, Cordylanthus pringlei, Senecio greenei and clevelandii, and Arctostaphylos elegans. Raillardella scabrida and Epilobium nivium are at higher altitudes on the north side of this area.

8. The Lucian ARea. This area includes the Santa Lucia Mountains, the only mountain range of the California coast overhanging the Pacific Ocean: Abies venusta, Cupressus goveniana, Chorizanthe vortriedei, breweri and palmeri, Streptanthus lemmonii, and Ribes sericeum.

9. The Santa Barbara INsular Area. An area which includes all the Santa Barbara Islands: Dissanthelium californicum, Quercus tomentella (also on Guadalupe Isl.), Eriogonum arborescens and giganteum, Arabis filifolia, 


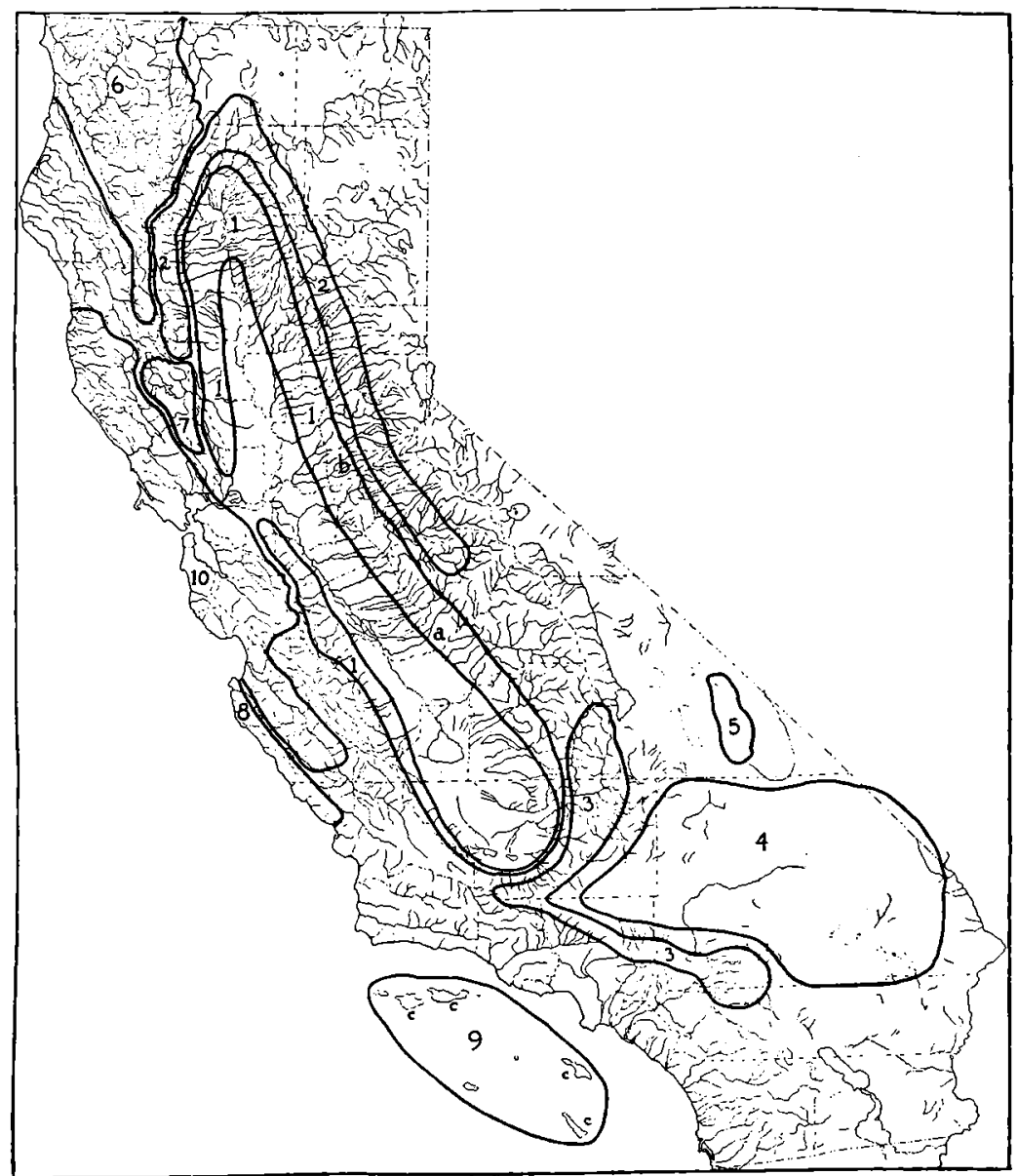

Some Endemism Areas in Califoriia. The numbers on the map refer to the numbered paragraphs on pages 12 and 13 . The letters refer to three remarkable endenics: $a$, Carpenteria californica; $b$, Arctostaphylos myrtifolia; $c$, Lyonothamnus floribundus.

Ceanothus arboreus, Convolvulus macrostegius (also on Guadalupe Isl.), Phacelia lyoni, Hieracium argutum, Hazardia cana, and Hemizonia clementina.

10. The Franciscan Area. This is an area extending from northern Monterey County to southern Mendocino County. It contains a large population of endemic shrubs (Jepson, Fl. W. Md. Cal. ed. 2, 4), and it is thought, a larger number of endemics than any other endemic area in California, but the area has not, as yet, been suffieiently studied from this viewpoint and its geographic limits are not clearly determined. Only a few species can here be listed: Iris longipetala, Chorizanthe pungens, Montia gypsophiloides, Arabis blepharophylla, Acaena pinnatifida var. californica, Thermopsis macrophylla, Hystrix californica, Ceanothus foliosus, papillosus, sorediatus and 
incanus, Dirca occidentalis, Navarretia abramsii, mellita and heterodoxa Orthocarpus floribundus, Cordylanthus mollis, Corethrogyne californica, Lessingia ramulosa, Micropus amphibolus, Layia chrysanthemoides and calliglossa.

\section{The Alien Populations}

Exotic species which have, through accidental or other introduction, become an integral part of the California flora number 292. These immigrants have been derived from all continents of the earth but ehiefly from the Mediterranean region. The number 292 gives no proper concept of these alien populations, since the species are often very aggressive, produced in countless numbers of individuals and have an important significance in relation to the dominance or persistence of native species which, in many cases, they successfully disposess. In the low valleys and in the open foothills there are many districts where the aliens make 50 to 75 per cent of the total population. Only aliens which are really established and have a true competitive status are included in this text. Many alien species that have been introduced are not as yet weil established or are only accidental or casual and often disappear. Likewise are excluded those cultivated plants which are transiently spontaneous or which may persist only in a protected spot.

\section{The Concept of Genera and Species}

The treatment of genera and species in this work differs markedly from that of certain authors, more particularly from those who have published new genera and species in an isolated manner and not in revisions, monographs or floras. The differences are sometimes very great, as, for example, in the genus Eschscholtzia. This text includes 7 species for California; Fedde in Das Pflanzenreich makes 100 species as occurring in California. The genus Ptelea is represented by one species as viewed by this Manual; Greene (Contrib. U. S. Nat. Herb. 10) has 6 species for California. Such instances might be multiplied almost indefinitely, and necessitate a statement as to the principles worked out and employed by the writer in the preparation of his systematic papers. A genus, in the view of the writer, should include all species of close genetic connection which have a marked natural resemblance or are closely bound together by structural peculiarities which indicate a close line of descent or form a compact natural group. Genera so founded are suffciently large to establish relationships on a recognizable scale and to bring out the intimate relationships which exist between floras of different regions or countries as a result of past migrations. Genera having marked characters should not be subject to a segregation which reduces the generic character to the level of a species character. It is, however, necessary that the limits of genera should, with increase of knowledge of their structure, probable phylogeny, geographic history and ecology, be subject to revision and modification. No genus has any vested rights on account of long usage or approval by great masters. Continued research, increased knowledge and an enlarged viewpoint must continually find vent in new generic expressions. Otherwise devotion to the past becomes a species of mental slavery wholly at variance with the spirit of seientific research.

Similar observations apply to the species unit. It must consist of individuals having the same genetic constitution, that is, bound together by intimate genetic connection as determined by the morphology, detailed structure, life history, genetic evidence, geographic history and ecologic status. The species should represent a natural unit, more especially from the geographic standpoint. It should be, as an objective aim, distinguishable from related units. It must have practical value or utility, that is, it must be useful in the scientific sense. Every effort should be made to give it clear definition. Ordinarily such a species will possess structural and ecological characters by which its identity can be established. Since species are so much more numerous than genera, the problems have likewise been more numerous than in the case of genera. Investigation by the author of a vast amount of original plant material and of a very large number of segregate 
species published for California and its neighboring states has developed certain guiding principles which are here set down as a condensed outline of his practice and serve to indicate broadly his mode of research, and the principles on which that mode is based.

1. RANGE OF VARIATION. By measurements and observation it has been the practice to secure as full data as is possible regarding variation in the organs of a species, especially from one individual or from a series of individuals, where these have common parentage, either directly known or obviously inferred. Such a mass of statistics is of primary importance in the problems of species.

2. Special Morphology. By field observations, by garden cultures or by laboratory methods the structure, character and presence or absence of plant organs has furnished invaluable data for determining the validity of species. The specific mark of a segregate, for example, is often described as the possession of an organ which is, in reality, present in all the segregate forms referred to. On the other hand microscopic study of morphologic detail has often revealed structural differentiae of the greatest importance for segregating new species or validating old ones. An illustration of the latter instance is afforded by the study of the trichome-like processes in the glands of Calochortus which furnished a new and more satisfactory basis for species differentiae in that genus (Jepson, Fl. Cal. 1: 291-302).

3. LIFE History. The entire life history of the plant forms an invaluable record in determining relationships and phyletic descent, because the successional stages of development in the individual exhibit certain characters or structures which, as critically weighed, are repetitions in a greater or less degree of the history of its race or line. This theory is summarized in the well-known biogenetic law, a renewed and able defense of which has recently been made by E. C. Jeffrey (Sci. 60: 531-1924). Osmaronia cerasiformis, a well-known species of the soft chaparral, belongs to the family Rosaceae, a family characterized by the presence of stipules. In Osmaronia stipules are absent or feebly developed only on young shoots; they are, when present, short vestigial structures and significantly indicative of ancestry. In connection with this general principle, it is to be noted that juvenile characters in certain individuals are sometimes prolonged or reappear in the adult stage, and have been seized upon as the basis for specific segregates. In addition specimens which merely represent extreme maturity on the one hand or extreme youth on the other, are frequently used as the basis for specific segregates. This is so commonplace that it would not require mention save that segregates with such a basis are sometimes published at botanical centers of admittedly high reputation. In general fuller data regarding juvenile stages are available than are data regarding extreme maturity, especially the stage of senescence or of death. An illustration of the value of what $I$ here call a senescence character is furnished by Cordylanthus pilosus, in which the writer has observed that the lower of the two sepals is deciduous in extreme age. This is a true senescence character. This species belongs to the subgenus Eucordylanthus, in which the calyx is diphyllous; in the section Hemistegia, which is here regarded as congeneric with Cordylanthus and not accepted as a separate genus, the calyx is monophyllous from the beginning, the upper sepal only being present. Physocarpus capitatus, a shrub of the soft chaparral, loses its stipules in extreme maturity and fails, therefore, to show a well-known family character at this stage. The valves of the capsule in Juncus drummondii become more distinctly retuse after dehiscence, in extreme age. This mark of senescence is a valuable specific character. All such instances, which appear like departures from the set family, genus or species character, should not be regarded by the student as annoying or irritating exceptions but as evidences of evolutionary trend which are full of genetic significance and pregnant with phyletic meaning.

4. Mutilation. Excision of the crown of an adult individual or of a portion of it or of particular organs or parts of organs, under appropriate conditions, often results in the production of a range of form not normally exhibited by the individual or not at that age. Such structures often throw 
valuable light on phylogeny. Annual species of Gilia, as an example, are often characterized by early or basal leaves of quite different shape or size from the floral leaves. By mutilation, a plant may be induced to exhibit only the type of leaves associated with the flowering stage. Not infrequently acci. dental mutilation may occur in a state of nature and individuals of this sort have been collected and, by certain authors, named and described as if good species.

5. Garden Cultures. Very few native plants have as yet been treated as cultures. This work is necessarily a slow one but the practice yields invaluable data regarding genetic relations and specific limits. As an illustration the case of Eschseholtzia may be cited. By transplanting individuals of Eschscholtzia californica from the Great Valley to the seacoast the writer was enabled to observe changes in a given individual which corresponded to characters of certain so-called segregates, while in the Great Valley he was enabled to demonstrate (Fl. Cal. 1:564-572) that one individual showed successively, during the long flowering period, certain phases which correspond with some five or six of the most extreme segregates in the large number of segregates artificially split away from that species. This work had great significance because it justifies the reduction of Eschscholtzia species from the total of 123 to a much smaller number, say about 10 or 20. Important results in the case of other genera are also on record.

6. Field Studies. The importance of field studies cannot be overestimated, for it is in the field that plants are growing under natural conditions. The most valuable records are those which relate to habit, life-history, soil, exposure, and associated species. The array and inter-relationship of forms in a plant community provides an exhibit of living phenomena which suggests solutions or clews to many problems which may be further developed by critical investigation. Vestigial structures often have great weight in relation to phylogeny and are often most easily discovered or clearly perceived in the field; while excellent examples of range of variation in organs can of ten be satisfactorily worked out in the field. For this purpose, in the course of the author's investigations, expeditions have been made to all parts of California over a period of several decades and have always been fruitful of results.

7. Indication of RANGe. No two species react similarly to a given combination of the climatic factors, but for each species there is an optimum area where it has its greatest development. In this area of greatest development the species has greatest range of tolerance and often grows in the widest variety of situations. As it radiates from this area it shows a more and more limited tolerance along each of the various lines of radii; that is, each radius exhibits it as keeping to a narrower and narrower set of conditions until the species reaches its limits. Since a species can, in certain respects, be studied to greatest advantage at the limits of its range, an attempt is here made to indicate range limits more accurately than has hitherto been attempted.

8. Bio-geographic Status. Most species grow under a comparatively narrow range of climatic conditions. The determination of geographic position and climatic status is always of importance in relation to validity of species. It not infrequently happens that the range of a species is successfully predicted in advance of exploration. Contrariwise it often happens that plants published as separate species but without geographic data seem, on the basis of their descriptions, lacking in the essentials of good species. It not infrequently falls out that the later investigator of such proposed species is enabled to determine that the forms in question belong to the same division of a life-zone, and he is thus afforded helpful clews to, or even essential confirmation of, specifie identity. Complete elucidation may follow naturally from the known laws of geographic distribution in the region.

9. FIELd Records. Records of observations or experiments in the field, must, in order to have real value, be made on the spot and at the time, and be further validated by herbarium specimens. Truly useful herbarium specimens consist of ample series and represent the widest possible phases of the life history. 
10. Writing of Diagnoses. The writing of diagnoses proceeded upon a definite plan, in order to give the best possible expression to the author's results. The ideal descriptions give an exposition of relationships and phylogeny which is in as nearly complete accord as possible with the facts of nature. All data, structural, morphological, ecological and physiological may aid in this task, while of course the herbarium is a constant resource. The construction of diagnoses, according to such a standard, is one of intense and prolonged labors, but such work not only serves to approximate a truthful account of the flora of a region but it also affords a means of judging proposed new species. The original description of a species and the type speci. men are invaluable for determining identity, but that once done, the origina. description has served its purpose. It is necessary that this original description, resting commonly on few individuals, or on a single one, or even on a slight fragment, should be supplanted by a diagnosis of the species which covers the species population as the species exists in a state of nature. Imperfect or diluted original descriptions have been made, too frequently, a plausible pretext for publishing segregates without real value. The writing of sound diagnoses is a highly important art because it helps to stabilize specific units.

It might seem that such a procedure as has been indicated is so obvious or so natural as not to require a statement of this kind. On the contrary, descriptions in certain floras are so frequently copied from other works that the fact of copying has come to be assumed, by many botanists, as if it were universal in the case of floras. Even E. Warming (Oecology of Plants, 1) speaks of "the compilation of a Flora." New descriptions, the result of prolonged field studies or garden experiments and containing new life-history material, are by the copyist conveniently copied, not infrequently under the impression that these descriptions are themselves copied ones. Even the copying of good deseriptions serves no useful purpose, simply because the making of floras by copying results in a mass of unrelated and unorganized material, a way of doing things which has done much to promote the multiplication of useless species.

11. Scientific ApProach. All problems of relationships and phylogeny that arise in a group must be resolved and interpreted after acquiring ample knowledge of the group and after fullest determination of the facts, without preconceived rules or prejudice. This is so well known and so fundamental a principle that it scarcely requires mention here, save that a contrary principle embodied in an ancient fallacy constantly reappears under a new and often engaging guise. By some method, it is said, the riddle of relationships for all plants can be solved: by the use of physiological traits, by the use of the carpel, by the use of stamens, by the use of biometric measurements (and so on down through the centuries), the species of the books may, by a given method, be made uniform. The answer to this is that characters of evaluation for a given group cannot be determined in advance. This matter can be partly illustrated by the writer's studies on the genus Aretostaphylos. From the standpoint of the practice of evaluation by morphologic characters, or by biometric measurements or by any other method determined in advance, scarcely more than five or six species could well be recognized for California. In this Manual 25 species are described, a larger number for California than has hitherto been accepted in any work. Based upon morphologic character these 25 species fall into a number of groups of 3 or 4 species each, the species being separable in herbarium specimens only by minute differences in pubescence, glaucescence, or foliage and the like, too slight for good evaluation. In their relation to chaparral fires, however, the species within each group react in a fundamentally unlike manner--some kill outright under fire of even slight intensity, others lose their crowns, but persist by root-crown sprouting even after the most destructive of chaparral fires. That is, the responses are constant and fundamentally unlike. This specifie segregation is further correlated with geographic and ecologic segregation and we have an excellent example of the working out of what I have called the biogeographic principle (Jepson, Madroño, 1: 76-96). This one illustration proves sufficiently that a scientific method cannot be determined in advance. 


\section{Climatic and Edaphic Variations and Parallel Variations}

The object of the diagnoses is to set forth the families, genera and species by descriptions based upon the prevailing or dominant type in each rank. It is hoped in this way to exhibit as clearly as possible the probable phylogeny, so far as it can be done in a linear sequence, and to bring out the salient facts which indicate relationship. No attempt is made to cover the range of mutating or fortuitous variation, or the ordinary climatic or edaphic variations. To do this fully in all its bearings might well require a volume of this size for a single species. To expect a diagnosis to apply exactly to an individual rather than to the species population which it describes is to demand that species be fixed invariable entities. No biological fact is, perhaps, better established than the fact of variation. No two individuals of any species of a seed-plant, we will say, are exactly alike. The student should, therefore, when making determinations, assemble by dissections and by observations and records the fundamental morphologic evidence in connection with field data. He should bear constantly in mind that careful determination represents exereise of the critical faculties. Even professional botanists sometimes imagine that the identity of a species and its phylogenetic position can be named offhand. This is merely a notion, and is, of course, entirely fallacious. For these reasons, the inexperienced user of this Manual should keep in mind the principle of non-inherited variations. A few illustrations of climatic and edaphic variations of this sort are indicated as follows:

1. Plants in rich soils or unusually favorable moisture conditions become much larger or ranker than the average of the species. One must, to be sure, on the one hand, distinguish between seasonal or local rankness and, on the other hand, large forms which represent gigantism, a condition which is inherited. Minor and major forms oceur in many genera. Typical Brodiaea laxa represents gigantism; its minor form is var. nimia. Typical B. coronaria is a minor form which has a major form in var. mundula.

2. In sterile soils or under unfavorable seasonal conditions a species may develop very small individuals, much smaller than described for the species This is particularly true of the large number of annuals in the Californian flora. A single illustration will suffice. In Sierran swales or under forest un. told millions of individuals of Gilia leptalea, simple-stemmed and only 1 to 3 inches high, grow in the granite sand. This species at lower altitudes is normally branched and 10 to 18 inches high. Extensive areas of dwarfs occurring with such marked uniformity are, to be sure, worth ecological notice, but they do not represent a genetic variation. One must again, how. ever, distinguish between these seasonal dwarfs and true pygmies, the latter representing nanism which is inherited.

3 . In many species size of flowers or size of heads is proportionate to size and vigor of the individual plants. Pentachaeta bellioides furnishes a striking illustration.

4. In wet soils or in swamps the plant tends to become succulent and also glabrous.

5. In valley loams growth is commonly much more rank than on hillsides or clay flats.

6. On hilltops plants tend to become dwarf and also stemless, as is frequently seen in the case of Eschscholtzia californica.

7. In cold soils or in beaten ground, stems and branches often tend to spread or even to become prostrate.

8. In strongly alkaline valleys or near the sea the tissues of individuals often tend to become more succulent or fleshy.

9. In subsaline soil the stems and foliage of many species are more vigorous and the flowers larger than on stiff clays or adobes.

10. In the deep shade of woods leaves become thinner and larger, the in. ternodes longer and the plants taller. In the shade of Redwoods on upper San Leandro Creek, for example, the shrub Cornus californica exhibits leaves 3 to 5 inches long; in the open 100 yards distant, its more usual situation, the leaves are 1 to 2 inches long and much thicker in texture. In shade, also, plants tend to become glabrous. 
11. In intense sunlight plants tend to be compact with short internodes and small leaves.

12. At high altitudes the flowers are larger in proportion to stature and brighter in color.

13. Plants growing in water have longer internodes and longer and often pointed leaves as compared with the terrestrial form with shorter blunt leaves. Jussiaea californica in deep water has elongated pointed leaves; the terrestrial form has shorter internodes and short and broad subrosulate leaves very obtuse at apex.

14. Plants growing in dry places or in situations which inhibit vigorous growth sometimes have entire leaves instead of serrate ones, as is the case with Pentstemon newberryi growing on lava cones.

15. Plants growing normally in wet or moist situations sometimes tend to become spinescent in arid situations, as is the case with Navarretia leucocephala.

16. Plants which in their early stages are subaquatic and produce fistulous phyllodes at this stage fail to develop phyllodes in dry seasons, though going on to maturity, as in the case of Eryngium vaseyi.

17. In early and warm rainy seasons annuals and biennials sometimes tend to become perennial.

18. Habital similarity of unrelated species. The phrase habital similarity, as here used, refers to the appearance of parallel or analogous structures in unrelated species, the structures evidently representing adaptation or physiological response to a like combination of the climatic and edaphic factors. A few apt illustrations may be grouped in types which $I$ have named as follows:

A. Polymitism (Mitophytes). Represented by annuals with numerous filiform or slender stems having a "bushy" habit, illustrated by such unrelated species as Eriogonum spergulinum and Nemacladus ramosissimus.

B. Prophalism (Prophalophytes). This habit is assumed by annuals which produce a single flower or a single head or a single spike of flowers at the ground under the earliest seasonal impulse, further growth being inhibited by dryness; or on the other hand, if favorable conditions continue, there will ensue a development of many ascending or decumbent branches proliferous from beneath the initial flowering, these later shoots giving rise to profuse flowering. This habit guarantees at least some seed in case of seasonal drought and occurs in such plants as Navarretia prostrata and Oenothera trichocalyx, species from families widely separated phylogenetically.

C. Simulism (Simulophytes). This is a case of pure habital similarity, a similarity in branching, in hue or in foliage, and is illustrated by the resemblance of such widely unrelated pairs of species as the following: forms of Navarretia squarrosa to forms of Centromadia pungens; Collomia rawsoniana and Clinopodium mimuloides; Lomatium parryi and Cymopterus anisatus (of the Great Basin) ; early stages of Dodecatbeon jeffreyi and Rumex occidentalis.

D. Proliferism (Proliferophytes). Certain species with a slender stem or main axis produce proliferous branches and in habit assume analogy to other species, as: Pentachaeta exilis, Rigiopappus leptocladus, Navarretia prolifera.

Obviously the student should be on his guard, against being misled by analogies or superficial resemblances, especially in the absence of reproductive organs from the material. A specimen of an old and well-known California species of Prunus (family Rosaceae) has recently been published by an American botanist as a new species of Lycium (family Solanaceae). He was misled by habital similarity due to definite external conditions ("epharmonic convergence"). The student, therefore, should always secure the fullest possible evidence from the sexual reproductive organs, especially the gynoecium or pistil, because the reproductive organs are, as to structure, removed (normally) from external influence. On the other hand the vegetative organs are freely subject to edaphic influence because they are directly concerned with the struggle for existence in the individual. In determining the morphologic value of an organ the facts should be established in the order of their importance, namely: 1. Position (the most important consid- 
eration). 2. Structure (also highly important). 3. Shape (of secondary value). 4. Size (of quite secondary value). 5. Color (its value is very slight). If the plant or material bears no sexual reproductive organs the student should observe great caution and reserve in determining its systematic affinities or phylogenetic position.

\section{Acknowledgments}

This volume provides the first Manual of the flowering plants and ferns of California. During the progress of its preparation, many thousands of notes and specimens have been contributed by Mr. Frank W. Peirson on the flora of the San Gabriel Mountains, by Mr. Joseph P. Tracy on the flora of Humboldt County, by Dr. A. L. Grant on the flora of the Sierra Nevada, by Dr. P. B. Kennedy on the flora of Fresno and Eldorado counties, and by Dr. L. N. Upton on the flora of the deserts. Many other correspondents, too numerous to mention, have sent special but important data. For all this valuable and timely aid the author returns his grateful thanks as well as to those contributors whose names appear in the text as authors of special families or genera. Dr. A. S. Hiteheock and Mrs. Agnes Chase furnished the manuscript for Gramineae, Mr. K. K. Mackenzie provided that for Carex, Mr. C. P. Smith contributed the text for Lupinus, while the Cactacea were done by Mr. S. B. Parish. For certain other parts I am indebted to my students: Dr. Alice M. Ottley did the genus Lotus, Miss E. M. Zeile attended to Castilleia and Mr. H. L. Mason drew up keys for Phlox and Polemonium. The drawings were chiefly done by Miss Joyce M. Saunders under the author's direction. Finally must be mentioned the work of Dr. C. B. Bradley in accenting the Latin names, a task characterized by his usual scholarship and erudition. Department of Botany, University of California, Berkeley, July 15, 1921.

Willis LinN JEPSON.

\section{Note on the Accentuation of the Latin Names By Cornelius Beach Bradley, LL.D.}

The scheme for marking the accentuation of plant-names in this work is that used in the current manuals. Both the acute and the grave accent-marks indicate that the vowels to which they are attached are to be stressed; but the grave ['] indicates further that vowel has its long sound in English, while the acute "'] indicates either its short sound or some other variation from the long. The accepted accentuation has been followed save in a few cases where it has seemed to be clearly mistaken. One such case is the little group of English surnames like Forbes and Jones, in which the $e$ is silent, and the words are monosyllabic. There seems to be no good reason why the addition of Latin suffixes should not only give sound to the silent $e$, but also ridiculously lengthen it. I bave therefore treated all such stems as monosyllabic, precisely as Johns would be treated in like circumstances; as, e. g. Jòn [e]si, Jün[e]sia, Jòn[e]siàna, ete. Another such group are the personal names ending in -son, with short, unstressed 0 . All the Latin forms built up from such stems bave therefore been accentuated on that basis, thus: Jóhnsoni, Jóhnsoniàna, but Johnsònia.

In Latin, moreover, there are many quasi-compounds, like our hyphenated compounds, in which both elements retain their separate accentuation. Such a compound is sempervirens-cf. Oxford Dictionary s.v. Semper. Naturally, therefore, the word has been regularly pronounced sémpervìrens-both by scholars and laymen. But some wiseacre has made the discovery that the $i$ of the penult is short, and a letermined effort seems to be made to spread the "correct" pronunciation sempervirens! The matter would deserve no notice here were it not that the attempted innovation seems almost an insult to our noble Redwood.

There remains a word more to be said concerning the unlucky suffix -oides, which seems to be generally mispronounced as a dissyllable, with the $o$ and $i$ coalesced into a diphthong, after the analogy of ovoid, thyroid, and mastoid. All such tabloids are of modern manufacture, and suited to the haste and impatience of our modern life. But $-\check{c}-t$-des is a leisurely and dignified mouth-filling trisyllable, and has been such at least ever since the Trojan War. 